\title{
ACERCAMIENTO A UN CICLO POÉTICO: LOS SALMOS DE MIGUEL DE UNAMUNO
}

\author{
Francisco Javier Escobar Borrego
}

\begin{abstract}
This paper is an analysis of the six Psalms published by Miguel de Unamuno in his first poetical work in 1907.
\end{abstract}

\section{LOS SALMOS DE UNAMUNO EN SU CONTEXTO: FUNDAMENTO Y TEMÁ- TICA.}

Un conjunto de salmos de Miguel de Unamuno -seis, en total- fueron publicados en el volumen Poesías primer libro poético del catedrático salmantino- en 1907 (Bilbao, imprenta de José Rojas). Aparecían recogidos bajo el epígrafe común de Salmos en la sexta sección de las dieciséis que componen Poesías; fueron dedicados por Unamuno a su amigo Mr. Everett Ward Olmsted (profesor de lo que era entonces la Universidad de Cornell) y presentan los siguientes títulos: Salmo I ("Señor, Señor, ¿por qué consientes"); Salmo II ("Fe soberbia, impía"); Salmo III ("Oh, Señor, tú que sufres del mundo"); ;Libértate, Señor! ("Dime tú lo que quiero"); La hora de Dios ("Es la hora de Dios, sobre la frente") y En el desierto ("iCasto amor de la vida solitaria..”). A este corpus debemos añadir otra composición, el Salmo de la Mañana (junio, 1907), que no vio la luz en dicho libro y que presenta una temática diferente respecto a los seis poemas mencionados, ya que, frente a la angustia existencial que manifiesta Unamuno en sus Salmos de Poesías por no recibir de Dios ninguna señal-, en el Salmo de la Mañana, por el contrario, encontramos el estado de júbilo y gozo del poeta al disfrutar, por fin, del signum o señal divina -la luz de la mañana-, que reaviva su fe en la existencia de Dios ${ }^{1}$.

Como bien se sabe, la crisis espiritual y cultural que dominó la literatura europea de Fin de siglo trajo consigo, entre otras cosas, la revalorización de la figura de Cristo ${ }^{2}$. Unamuno

\footnotetext{
${ }^{1}$ Citamos los Salmos de Poesías por la edición de A. Suárez Miramón (M. de Unamuno, Poesía Completa, I, Madrid, Alianza, 1987) y el Salmo de la Mañana, que fue publicado en la revista Renacimiento (Madrid, $n^{\circ} 10$, diciembre, 1907, pp. 690-694) y recogido por M. García Blanco (Don Miguel de Unamuno y sus poesías, Salamanca, Universidad de Salamanca, 1954, pp. 380-384), por la citada edición de A. Suárez Miramón: Poesía Completa, IV, Madrid, Alianza, 1989, pp. 60-63. Para una aproximación al volumen Poesías, vid.: R. de Garciasol, Unamuno: al hilo de "Poesías", 1907, Madrid, Sociedad General Española de Librería, 1980.

${ }^{2}$ Sobre la revitalización de la figura de Cristo en la literatura europea de Fin de siglo, vid. H. Hinterhäuser, "El retorno de Cristo", en Fin de siglo. Figuras y mitos. Trad. de M. T. Martínez, Madrid, Taurus, 1980, pp. 15-39. Lectura que puede complementarse con el capítulo "La espiritualidad modernista", en G. Azam, La Obra de Juan Ramón Jiménez, Madrid, Editora Nacional, 1983, pp. 233-257, con abundantes referencias a Unamuno y su influencia en Juan Ramón; y del mismo autor, El modernismo desde dentro, Barcelona, Anthropos, 1989.
} 
no es ajeno a este contexto finisecular y buena prueba de ello dan sus Salmos, fruto de una profunda crisis espiritual del escritor que comienza en 1897 y que marcará de un modo decisivo su trayectoria literaria ${ }^{3}$ Al igual que otros poetas de su generación -A.Machado, por ejemplo-, Unamuno siente la necesidad de buscar el sentido de la vida y, para ello, pide a Dios una señal de su existencia, ya sea mediante la palabra o bajo el deseo anhelante de que Dios̀ se le haga presente:

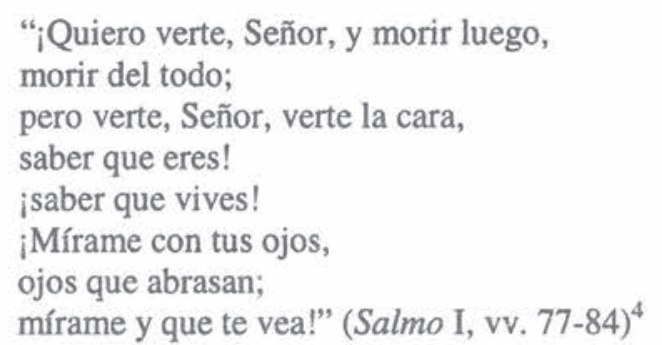

Esta crisis religiosa del poeta se produce como consecuencia del conflicto interior entre la razón y el conocimiento por fe, tal como señala Unamuno en su Salmo II:

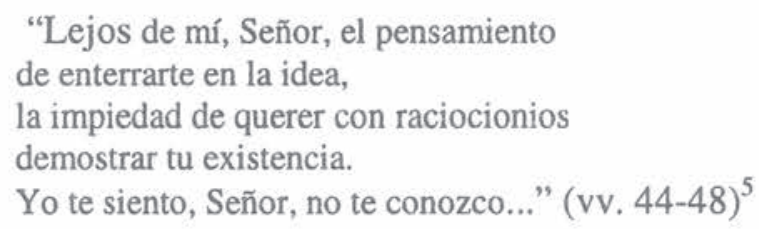

Por lo que hace a su conformación literaria, los Salmos unamunianos suponen un punto de confluencia entre los elementos, motivos y símbolos definidores de la tradición salmística y la propia aportación personal del escritor. En cuanto a lo primero, Unamuno actualiza y recrea de un modo literario expresiones y personajes bíblicos (Jacob y Moisés, por ejemplo) y continúa la tradición del género literario, siguiendo las huellas de la poesía religiosa de Fray Luis de León, San Juan de la Cruz o Francisco de Quevedo ${ }^{6}$. Por otra parte y como sublimación literaria de su crisis espiritual, Unamuno se distancia y rebela contra esta tradición salmística que le precede y que da por sentada su fe en Dios. Esta concepción creadora cristaliza luego en su poesía religiosa posterior, a saber, en sus sonetos espirituales de 1910

\footnotetext{
${ }^{3}$ Cf. A. Sánchez Barbudo, "La fe religiosa de Unamuno y su crisis de 1897", Revista de la Universidad de Buenos Aires, XVIII (1951), pp. 381-443; trabajo revisado como "Una experiencia decisiva: la crisis de 1897", en A. Sánchez Barbudo, Estudios sobre Galdós, Unamuno y Machado, Barcelona, Lumen, 1981, pp. 88-122; A. Zubizarreta, Tras las huellas de Unamuno, Madrid, Gredos, 1960; Ch. Moeller, Literatura del s. XX y cristianismo, Madrid, 1964, pp. 97-144; E. Rivera, "La crisis religiosa de Unamuno", Cuadernos de la "Cátedra Miguel de Unamuno", XVI-XVII (1966-1967), pp. 107-133; y C. Forment, "La agonía religiosa en Unamuno", en A. A. V. V.: Cincuentenario de la muerte de Unamuno, Barcelona, Fundació Caixa de Pensiones, 1988, pp. 75-107.

${ }^{4} \mathrm{PC}, \mathrm{I}, 110$.

${ }^{5} \mathrm{PC}, \mathrm{I}, 113$.

${ }^{6} \mathrm{La}$ influencia de la poesía religiosa de los Siglos de Oro en Unamuno fue ya destacada por Juan Ramón Jiménez, que define a Unamuno como poeta simbolista, no porque haya seguido la moda francesa, sino porque emplea símbolos como lo hacen San Juan de la Cruz o Fray Luis de León (El Modernismo. Notas de un curso (1953). Ed. de R. Gullón y E. Fernández Méndez, Madrid / México / Buenos Aires, Aguilar, 1962, p. 233).
} 
y en El Cristo de Velázquez (1920), y dejará posteriormente su impronta más notable en poetas como Jorge Guillén o Blas de Otero.

Los salmos, por su propia naturaleza, presentan una variedad temática que comprende argumentos como la lucha continua entre el bien y el mal, la confesión de los pecados, la narración de determinados sucesos culminantes de la historia de Israel, la gloria de Dios, su poder, su sabiduría, etc. Unamuno, por su parte, sigue este gusto por conjugar temas diversos, pero los subvierte para manifestar desde su concepción artística y creadora el desgarramiento espiritual que experimenta en esta época. De ahí que para nuestro escritor, sus Salmos no sean sino el reflejo literario de una poética del dolor y la angustia que se exterioriza mediante "los gritos del corazón":

"En nuestra menguada literatura apenas se le oía a nadie gritar desde el fondo del corazón, descomponerse, clamar. El grito era casi desconocido. Los escritores temían ponerse en ridículo. (...) Yo, no; cuando he sentido ganas de gritar, he gritado. Jamás me ha detenido el decoro. Y esta es una de las cosas que menos me perdonan estos mis compañeros de pluma, tan comedidos, tan correctos, tan disciplinados hasta cuando predican la incorrección y la indisciplina. Los anarquistas literarios se cuidan más que de otra cosa, de la estilística y de la sintaxis. Y cuando desentonan, lo hacen entonadamente; sus desacordes tiran a ser armónicos. Cuando he sentido un dolor he gritado, y he gritado en público. Los salmos que figuran en mi volumen de Poesías, no son más que gritos del corazón, con los cuales he buscado hacer vibrar las cuerdas doloridas de los corazones de los demás." 7 .

Cada uno de los Salmos unamunianos desarrolla un tema fundamental sobre el que giran otros que se relacionan con él. De esta manera, el Salmo I presenta como argumento central la búsqueda por parte del poeta de una prueba o signum que demuestre la existencia de Dios y que ofrezca la conversión de los ateos:

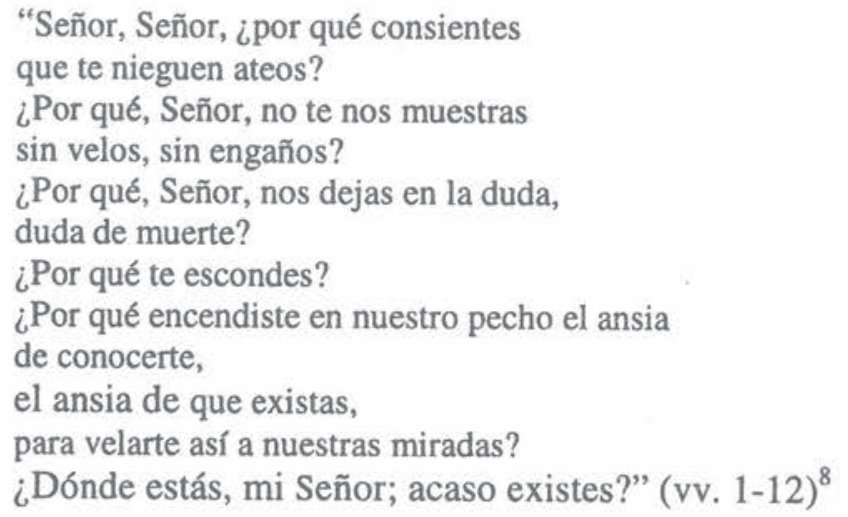

A este leitmotiv principal se le subordinan otros como el de la duda existencial, la creación divina, la vida como valle de lágrimas, etc. Del mismo modo, el Salmo II tiene como

\footnotetext{
7 "Mi religión", en M. de Unamuno, Ensayos, II, ed. de Bernardo G. Candamo, Madrid, Aguilar, 1970, pp. 373374 .

${ }^{8} P C, \mathrm{I}, 108$.
} 
eje central la problemática del conocimiento racional de la esencia divina frente al sentimiento vital, sin que esto impida el desarrollo de otros temas como, por ejemplo, la preocupación por el sentido de la vida y de la muerte. Sirviéndose de un exorno retórico y paradójico cercano al lenguaje de nuestros místicos, afirma el poeta:

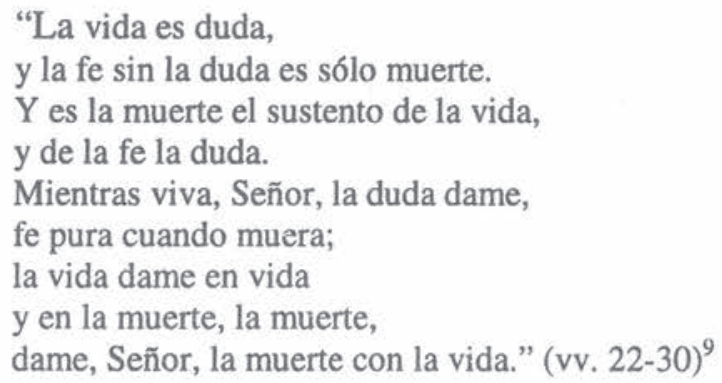

Los motivos literarios expuestos en los Salmos I y II (la creación, la búsqueda de Dios, etc.) reaparecen en el Salmo III, que se basa, fundamentalmente, en la cristología y pasión de Dios hecho hombre:

"Por gustar, joh, Impasible!, la pena

quisiste penar,

te faltaba el dolor que enajena,

para más gozar.

Y probaste el sufrir y sufriste

vil muerte en la cruz,

$\mathrm{y}$ al espejo del hombre te viste

bajo nueva luz." $(\mathrm{vv} .29-36)^{10}$

El canto ¡Libértate, Señor! presenta una naturaleza de plegaria o ruego a Dios -con enjundia y firmeza- para que libere no sólo a la humanidad de su sufrimiento y esclavitud, sino también a Sí mismo:

“ Mira, Señor, que mi alma

jamás ha de ser libre

mientras quede algo esclavo

en el mundo que hiciste,

y mira que si alma no libertas,

al alma en que Tú vives,

serás en ella esclavo,

Tú, Tú mismo, Señor!

¡Libértate!” (vv. 50-58) ${ }^{11}$

\footnotetext{
${ }^{9}$ PC, I, 113. La asimilación por parte de Unamuno de la mística española culminará en el Cristo de Velázquez: "Ahora voy a dar un poema sobre el Cristo de Velázquez. Es un intento de formular poéticamente el sentimiento religioso castellano, nuestra mística" (carta del 20/02/1914 a Texeira de Pascoaes); apud., M. García Blanco, op. cit., p. 215. Asimismo, Juan Ramón Jiménez consideró el Cristo de Velázquez como una paráfrasis -aunque sin llegar a imitarlo- de los Nombres de Cristo de Fray Luis de León (El Modernismo, p. 128). Sobre este poema unamuniano está centrado el trabajo de Schökel: "Poesía bíblica de Unamuno", recogido en L. Alonso Schökel y E. Zurro, "Mis fuentes están en ti". Estudios biblicos de literatura española, Madrid, Universidad Pontificia Comillas, 1998, pp. 183-242.
}

${ }^{10} \mathrm{PC}, \mathrm{I}, 115$. 
La hora de Dios, por otra parte, entronca con la corriente de los salmos penitenciales -vigente en la Literatura Española desde la Edad Media hasta la época contemporánea- ${ }^{12}$ y muestra al escritor en una actitud de confessio por una culpa (he aquí la paradoja) que desconoce y por la que sufre:
"Acepto este dolor por merecido, mi culpa reconozco, pero dime, dime, Señor, Señor de vida y muerte, ¿cuál es mi culpa?
Sí, yo pequé, Señor, te lo confieso, culpable tu castigo me revela, mi vida sin sufrir ya no es mi vida, mas... ¿por qué sufro?" (vv. 45-52) ${ }^{13}$

Finalmente, En el desierto, poema que cierra este corpus de salmos unamunianos, expone la búsqueda de Dios en un espacio alegórico de influencia bíblica y en el que el poeta anhela estar a solas con su Dios solitario:

\begin{abstract}
"Dejadme solo y solitario, a solas con mi Dios solitario, en el desierto; Me buscaré en sus aguas soterrañas recio consuelo." (vv. 57-60) $)^{14}$
\end{abstract}

El Salmo de la Mañana (junio, 1907) presenta -como hemos señalado anteriormenteuna diferencia esencial respecto al corpus salmístico de Poesías, ya que, si en los seis salmos de este libro podemos sentir el grito desgarrado de Unamuno por no recibir ninguna señal de Dios que le permita reavivar su fe, en el Salmo de la Mañana, por el contrario, encontramos al poeta gozando de la señal divina (la "luz de la mañana"), que tanto anhelaba:
"Acabo de nacer, Señor; un nuevo mundo has abierto a mis ojos, que del sueño resurgen renovados; el día es porvenir, es como un cielo sin nubes, acerado en su lisura." (vv. 1-4)

\footnotetext{
${ }^{11} P C, \mathrm{I}, 117$.

${ }^{12}$ Sobre los dos tipos de salmos penitenciales (de requisitoria y de confesión), véase el libro fundamental de Luis Alonso Schökel y Cecilia Carniti, Salmos I, Navarra, Verbo Divino, 1994, p. 104. Por su parte, María Wenceslada de Diego Lobejón ofrece una recopilación de salmos penitenciales a lo largo de la historia de nuestra literatura en su estudio: Los Salmos en la Literatura Española, Valladolid, Secretariado de Publicaciones e Intercambio Científico, Universidad de Valladolid, 1996.

${ }^{13} P C$, I, 120. Sobre el concepto de "confesión” en Unamuno, Teresa Imícoz Beunza señala lo siguiente: “(...) El poeta se confiesa públicamente, muestra a los demás su yo, de forma que cada uno pueda descubrir, mirándose en el poeta como en un espejo, su propio yo". (La teoría poética de Miguel de Unamuno, Pamplona, Universidad de Navarra, 1996, p. 31).

${ }^{14} P C, 1,122$.

${ }^{15} P C, \mathrm{IV}, 60$.
} 
Esta diferencia que presenta el Salmo de la Mañana respecto a los otros salmos pudo ser un factor decisivo para que Unamuno no incluyese en su libro de 1907 un poema en el que, por fin, Dios enviaba al poeta una señal: "Es la hora del milagro; / me despertó la vida." (vv. 6-7 $)^{16}$. Cuando aparece este signum divino, el universo renace, se ha producido el "milagro" y el hombre encuentra respiro en la "pobre tierra, cuna y sepulcro" (expresión con evidentes resonancias quevedianas):

"Sobre las aguas va el Espíritu Divino incubando cual fuera allá en la aurora de esta mi pobre tierra, cuna y sepulcro; sobre las aguas va sembrando a manos llenas santos propósitos" (vv. 8-13) ${ }^{17}$

Unamuno realiza una contraposición entre la señal divina portadora de luz y símbolo de esperanza, la "mañana"- y la "tierra", en la que el hombre vive en la más desdichada miseria y simbolizada en el poema mediante imágenes poéticas como, por ejemplo, la "noche":
"Dame, Señor, el beso regalado
que al despertar al hijo le da el padre, el beso en que el misterio de la noche se hace revelación del claro día; dame el viático con que a la noche llegue." (vv. 30-35)18

Como podemos apreciar en este pasaje señalado, la imagen poética del "beso" representa una variatio estilística de la "mañana" como señal divina. También el contenido simbólico de la "noche" es desarrollado en el Salmo de la Mañana mediante otras metáforas como la del "ambiguo murciélago sombrío":

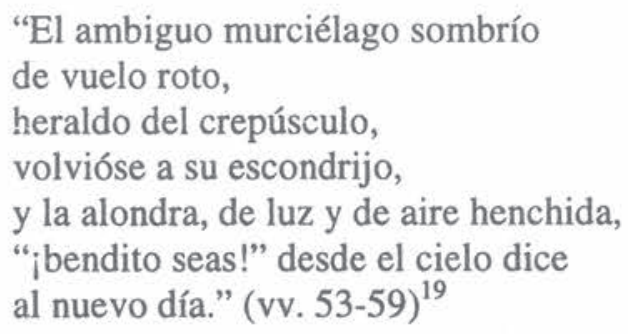

\footnotetext{
${ }^{16} \mathrm{PC}$, IV, 60 .

${ }^{17} \mathrm{PC}, \mathrm{IV}, 60-61$.

${ }^{18} P C, \mathrm{IV}, 61$.

${ }^{19} \mathrm{PC}, \mathrm{IV}, 62$.
} 
En definitiva, cuando llega la "mañana", Dios hace posible que el poeta se sienta "omnipotente" y "despierte a la vida" (vv. 89-103) ${ }^{20}$. La "Luz" ('Dios') es, ahora, el eje conductor de la vida del poeta.

\section{ELEMENTOS DE TRADICIÓN BÍBLICA Y LITERARIA.}

Sin separarse del contenido esencial de los salmos tradicionales, Miguel de Unamuno presenta al hombre en un estado de sufrimiento, duda y ansia de comunicarse con Dios a causa del pecado. El poeta llama a Dios y le pide una respuesta -ya sea de tipo visual o mediante la palabra- para obtener la liberación espiritual de su sufrimiento. Con esta súplica o plegaria, el hombre puede resolver su duda existencial y otras cuestiones metafísicas u ontológicas, que tanto preocupaban a Unamuno y a nuestros clásicos, como Fray Luis de León:

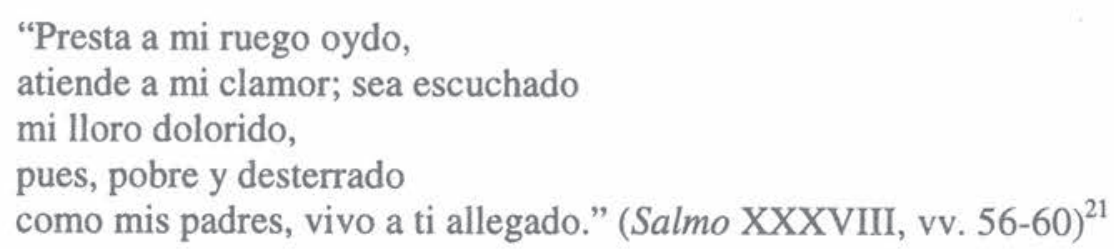

El último eslabón del proceso comunicativo que se lleva a cabo en los salmos tradicionales entre el hombre y Dios -la respuesta del ser divino-, está presente en nuestros poetas clásicos, no así en Unamuno, que sólo encuentra un Dios impasible, tácito y solitario:

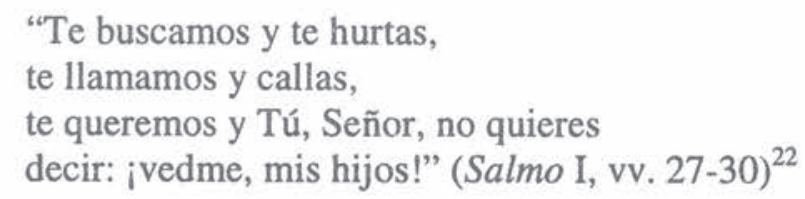

Por otra parte, debemos señalar cómo el proceso compositivo del salmo tradicional culmina con el canto de alabanza a Dios; sin embargo, en los Salmos unamunianos, al no haberse producido la comunicación entre el hombre y Dios, no tiene lugar dicho canto.

En su actualización y recreación de los Salmos, Unamuno se sirve de expresiones y símbolos bíblicos, que disemina a lo largo de sus piezas poéticas. Analizamos, en este sentido, las principales características de los Salmos I y II contenidas también en el resto de los Salmos del poeta.

En el Salmo I, por ejemplo, encontramos expresiones como "y todo vanidad de vanidades" (v. 44), "quien a Dios ve se muere" (v. 106), "yo soy" (vv. 90, 91, 123, 125) ) $^{23}$; y episodios bíblicos, como el de la aparición de Dios a Moisés en el monte Sinaí (Éxodo XXIV,

\footnotetext{
${ }^{20} P C, \mathrm{IV}, 62-63$.

${ }^{21}$ Fray Luis de León, Poesías Completas, ed. de C. Cuevas, Madrid, Editorial Castalia, 1998, p. 451.

${ }^{22} P C, \mathrm{I}, 109$.

${ }^{23}$ Tales expresiones remiten, respectivamente, a Eclesiastés. I, 2. Éxodo XIX, 21; XX, 19. Éxodo III, 14.
} 
16-17), o la lucha de Jacob con el ángel (Génesis, XXXII, 24-32)24. En cuanto a la simbología presente en esta pieza poética, cabe destacar diversas imágenes de raigambre bíblica como el mar (v. 21), la señal (v. 31), los esclavos (v. 53), la roca (v. 59), los ojos (vv. 82, 83), la nube (v. 101), la gloria (v. 103), el velo (vv. 4, 26), el nombre (vv. 113, 114), las tinieblas (vv. 97, 137), el tabernáculo (v. 100), el camino (v. 132), etc.

No faltan, por otra parte, en el Salmo I ecos de la mística española y, así, por ejemplo, el verso unamuniano " ¿dónde te escondes? (v. 26) recuerda el incipit del Cántico Espiritual de San Juan de la Cruz. De la misma manera que los versos "Ya de tanto, buscarte / perdimos el camino de la vida." (vv. 131-132) evocan a Santa Teresa cuando muestra de manera paradójica cómo el alma se encuentra errante en la búsqueda de Dios. Este aspecto de Unamuno fue advertido por Rubén Darío, que en sus Semblanzas se refiere al poeta vasco como "místico de última hora"; y por Juan Ramón Jiménez, que relaciona la concepción religiosa de Unamuno con la poesía de nuestros místicos ${ }^{25}$.

En el Salmo II, Unamuno se muestra más moderado en la utilización de elementos bíblicos y acusa, por otra parte, la influencia de la poesía religiosa española que le precede. Así, el pasaje en que trata la temática espiritual de la muerte como descanso final y conocimiento absoluto de Dios o la Verdad divina, entronca directamente con el pensamiento ascético:

\author{
"Eres, Verdad, la muerte; \\ muere la pobre mente al recibirte. \\ Eres la Muerte hermosa, \\ eres la eterna Muerte, \\ el descanso final, el santo reposo;" (vv. 12-16)
}

Ya anteriormente, había mostrado Unamuno su preocupación por este tema en la Vida de Don Quijote y Sancho (1904): "En la muerte se revela el misterio de la vida, su secreto fondo" (II, LXXIV) ${ }^{27}$. Mas en los Salmos de 1907, el poeta enfoca el tema de la muerte en clave similar a la de los místicos y expresa desde un punto de vista formal su sentido críptico y enigmático a través del procedimiento retórico de la paradoja:

\footnotetext{
24 "Del Sinaí desgarra las tinieblas / y enciende nuestros rostros, / como Moisés el rostro le encendiste; / baja, Señor, a nuestro tabernáculo, / rompe la nube, desparrama tu gloria por el mundo / y en ella nos anega;" (Salmo I, vv. 97-103); y “iMira, Señor, que va a rayar el alba / y estoy cansado de luchar contigo / como Jacob lo estuvo!" (Salmo I, vv. 110-112), respectivamente.

${ }^{25}$ R. Darío, Semblanzas, en El modernismo y otros ensayos, ed. de Iris M. Zavala, Madrid, Alianza, 1989, p. 148; y más explícitamente J. Ramón Jiménez: "Unamuno. Teología y mitología. Las dos tratan de los dioses. Fray Luis de León profano: místico renacentista. San Juan de la Cruz: místico arrobado. Unamuno: teólogo mitológico. Egoísta de la eternidad; monólogo sempiterno... (...) Relación con Santa Teresa en lo quijotesco (hubiera sido curioso que se hubiera encontrado con él [Unamuno] Santa Teresa, en vez de encontrarse con San Juan de la Cruz)." (El Modernismo, p. 118).

${ }^{26} P C, \mathrm{I}, 112$.

${ }^{27}$ M. de Unamuno, Vida de Don Quijote y Sancho, ed. de A. Navarro, Madrid, Cátedra, 1998, p. 506. Unamuno comparte con otros escritores de Fin de siglo el gusto por el paralelismo entre Don Quijote y Cristo (H. Hinterhäuser, op. cit., pp. 36 ss.).
} 
"Dame vivir en vida,

dame vivir en muerte,

dame en la fe duda en tanto viva,

dame la pura fe luego que muera." (vv. 36-39)28

Por otro lado, Unamuno actualiza en este Salmo II el proceso místico según el cual, el pensamiento es suspendido en el momento de la unión con Dios y el hallazgo de la Verdad divina: "muere la pobre muerte al recibirte" (v. 13); y también:

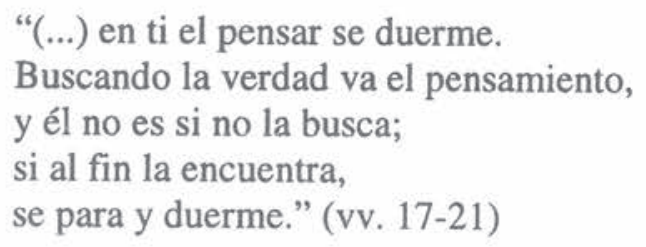

Esta misma idea la encontramos en Santa Teresa de Jesús, al explicar el tercer grado de oración: "Digo que en tan alta oración como ésta (que cuando la da Dios a el alma, puede hacer todo esto y mucho más, que éstos son sus efetos) entiende que lo hace sin ningún cansancio del entendimiento"; más adelante, Santa Teresa señalará: "Ahora pues, acaece muchas veces esta manera de unión que quiero decir (...) que coge Dios la voluntad, y aun el entendimiento, a mi parecer, porque no discurre, sino está ocupado gozando de Dios, como quien está mirando y ve tanto que no sabe hacia dónde mirar"29. San Juan de la Cruz, por su parte, desarrolla el motivo de la quietud espiritual en su poema En una noche obscu$r a$ (estr. 8).

El resto de los salmos combina las características ya analizadas y, así, encontramos, por ejemplo, el motivo poético de la cristología que expone Unamuno en el Salmo III -y que culminará con el Cristo de Velázquez (1920)-, o la alegoría del desierto en la última pieza religiosa de este corpus salmístico de Poesías.

\section{LA MÉTRICA DE LOS SALMOS.}

Lo primero que llama la atención es la frecuencia con la que Unamuno recurre al verso suelto, tanto en los Salmos como en poemas del libro ${ }^{30}$. Este dato trae inevitablemente a la

\footnotetext{
${ }^{28} P C, \mathrm{I}, 113$. Esta preocupación por la muerte como vida verdadera, eterna y de unión con Dios aparece ya en San Juan de la Cruz en sus Coplas de el alma que pena por ver a Dios (Cántico espiritual. Poesía, ed. de C. Cuevas, Madrid, Alhambra, 1979, pp. 340 ss.) y en Francisco de Quevedo en el Salmo 16: "Ven, ya miedo de fuertes y de sabios..." (Poesía varia, ed. de James O. Crosby, Madrid, Cátedra, 1992, p. 113).

${ }^{29}$ Santa Teresa de Jesús, Libro de la vida, ed. de Dámaso Chicharro, Madrid, Cátedra, 1993, pp. 240-241 y 243, respectivamente.

${ }^{30}$ Por ejemplo: La flor tronchada (sección Cantos; PC, I, 98-103); Alborada espiritual (sección Meditaciones; PC, I, 143-147); En una ciudad extranjera (sección Meditaciones; PC, I, 165-171); La catedral de Barcelona (sección Cataluña; PC, I, 83-85), etc. Esta incursión de Unamuno en el nuevo camino que le ofrece el verso sin rima se prolonga en diversos poemas de la misma época no incluidos ni en Poesías ni en el Rosario de sonetos líricos, por ejemplo: La peregrina, Mano en la sombra, Atardecer de estío en Salamanca y Al Nervión, perteneciente este último al libro Andanzas y visiones españolas (1922). Cf. M. García Blanco, op. cit., pp. 373-374, 377. $379,138-139$ y 242 , respectivamente.
} 
memoria el conocido poema A la rima (incluido en la sección de "Sonetos" de Poesías), en el que describe metafóricamente este recurso métrico como un lastre que impide al poeta expresar su sentimiento con libertad:

"Macizas ruedas en pesado carro,

al eje fijas, rechinante rima,

¡con qué trabajo llegas a la cima

si al piso se te pone algún guijarro!" (vv. 1-4)

Se trata en definitiva de un recurso destinado a encontrar la forma de expresión adecuada a lo que Unamuno denomina sus "gritos del corazón" 32 . El verso suelto culminará, dentro de la trayectoria poética de Unamuno, con el libro que algunos consideran su obra maestra: el Cristo de Velázquez (1920).

Tres son los esquemos métricos que encontramos en los Salmos de Unamuno, a saber: la silva de versos endecasílabos, heptasílabos y pentasílabos (Salmo II y ;Libértate, Señor!) con dos variantes, una que incluye el eneasílabo (Salmo I) y otra, el alejandrino (El Salmo de la Mañana); la estrofa sáfica -que consta de tres endecasílabos y un pentámetro adónico(En el desierto y La hora de Dios); y la estrofa tetrástica de decasílabos y hexasílabos alternos con rima consonante, también alterna (Salmo III).

Silva.

El Salmo II y ¡Libértate, Señor! presentan como combinación métrica una silva de versos endecasílabos, heptasílabos y pentasílabos ${ }^{33}$. En una carta dirigida al escritor uruguayo Carlos Vaz Ferreira (del 29/05/1907), Unamuno refiere la novedad de esta combinación de versos:

"La mayor novedad técnica de mis versos -escribe- es la silva en verso libre de pentasílabos, eptasílabos [sic] y endecasílabos. He llegado, a posteriori, claro está -yo hago los versos a oído, y no a ojo- a su teoría.

Estoy conforme con usted en que el verso simple más largo es el de nueve sílabas. En la primera época sólo usaban los simples o los juntaban con combinaciones homólogas, para

\footnotetext{
${ }^{31}$ PC, I, 224. Ya Juan Ramón Jiménez llamó la atención sobre el gusto de Unamuno por los versos sin rima, cuyo antecedente más claro parecía ser -en opinión del moguereño- la poesía grecolatina (El Modernismo, p. 116). Sin embargo, Unamuno menciona como modelo de sus versos sueltos al poeta italiano G. Carducci (1835-1907).

${ }^{32}$ Vid. F. Yndurain, "Unamuno en su poética y como poeta", en Clásicos modernos. Estudios de crítica literaria, Madrid, Gredos, 1963, pp. 59-125. Un posible precedente en la utilización del verso sin rima para composiciones de inspiración bíblica lo proporciona la Exposición parafrástica del Psalterio y de los cánticos del breviario (Madrid, 1623) de J. de Valdivieso (1560-1638); vid. Schökel, "Traducciones rítmicas de salmos", en "Mis fuentes están en $t i^{\prime \prime}$. , pp. 248-250.

${ }^{33}$ Sobre la silva modernista, vid. T. Navarro Tomás, Métrica española. Reseña histórica y descriptiva, Barcelona, Labor, 1983, pp. 401-402. Por otra parte, encontramos como antecedente de Unamuno (aunque con variaciones) diversas traducciones de textos bíblicos en la literatura española; por ejemplo, la paráfrasis del "Sicut cerva" (Sal 42) realizada por Malón de Chaide o la Selva Sagrada (1661) del Conde de Rebolledo, que presentan como cauce métrico la silva con rima consonante. Cf., en este sentido: Schökel, "Traducciones rítmicas...", en "Mis fuentes están en $t i " . .$, pp. 250 ss.
} 
hacer de dos de cinco uno de diez, de dos de seis uno de doce, de dos de siete uno de catorce. Pero oyeron que había versos de distinta medida que podían combinarse, v. gr., los de cinco con los de siete en combinaciones análogas. Se hicieron, pues, combinaciones de versos de cinco y de siete -sería mejor llamarlos de cuatro y de seis, tomando por norma el agudo-, y resultó alguna vez que terminando uno en vocal y empezando con vocal y empezando con vocal el otro, se unieron. Y de aquí resultaron los dos endecasílabos. Así, uno de siete más uno de cinco, enlazados por el hiato es lo normal entre nosotros, con el acento del eptasílabo en la sexta. Y el otro, el llamado de gaita gallega, de un pentasílabo más un eptasílabo (...) Este tiene acentos en la cuarta -la del pentasílabo-, en la octava y en la décima. ¿De dónde viene el de la octava? Acaso de que el eptasílabo más sonoro le tiene en la cuarta.." 34

Unamuno, al explicar en esta carta su teoría sobre la silva y justificar el empleo, en una misma composición, de versos pentasílabos, heptasílabos y endecasílabos, entiende que estos tres tipos de versos están relacionados, ya que, en su opinión, el endecasílabo contiene un pentasílabo y un heptasílabo. Ahora bien, la composición de la silva es -como ya ha señalado-"a oído":

"Vea, pues, cómo me salen, a oído, repito, silvas en que meto eptasílabos y pentasílabos mezclados y sueltos y otras veces enlazados en el endecasílabo compuesto. Y observe que lo ordinario es combinar endecasílabos con uno de sus componentes, ya con pentasílabos, ya con eptasílabos." 35

Unamuno considera fundamental apreciar el ritmo para entender su poesía y, para ello, es necesario "saber leer" y no como, en opinión del rector salmantino, hacen "quienes no se atreven a hincar el diente a la sustancia" (carta de abril de 1907 a Mariano Miguel de Val):

"Y así les pasará a mis Poesías -escribe-. Usted verá que la mayor parte están compuestas con arreglo a la preceptiva tradicional -aunque yo estime ésta mezquina y escolástica-, y las demás en ritmo libre, pero con su ley, y muchas al modo de Carducci y Leopardi. Pues bien: a esto se agarrarán los que no se atrevan a hincar el diente a la sustancia. (...) Usted sabe que los primeros versos se hicieron para cantarlos y acompañar al baile. Y los míos no son bailables. Agregue que la gente no sabe leer" ${ }^{36}$.

Una variante de la silva presenta el Salmo I de Unamuno, que consta de 163 versos sueltos en endecasílabos, eneasílabos, heptasílabos y pentasílabos. Del mismo modo, el Salmo de la Mañana está compuesto en versos de cinco, siete, once y catorce sílabas, sin rima $^{37}$.

34 Apud., M. García Blanco, op. cit., pp. 28-29.

35 Apud., M. García Blanco, op. cit., p. 29.

36 Apud., M. García Blanco, op. cit., p. 112.

${ }^{37}$ En opinión de M. García Blanco, el Salmo de la Mañana incluye versos de trece sílabas (op. cit., p. 131), mientras que, para T. Navarro Tomás, los versos son alejandrinos (op. cit., p. 407). Por nuestra parte, podemos decir que los presuntos tridecasílabos del Salmo de la Mañana -como, por ejemplo, "Acabo de nacer, Señor, un nuevo mundo" (v. 1)-, responden al tipo de verso llamado alejandrino a la francesa, en el que el primer hemistiquio 
En un principio, parece que Unamuno, al elegir este cauce métrico, debió tener presente la silva modernista; por ejemplo, R. Darío -en Cantos de vida y esperanza de 1905- escribe el poema Helios en una combinación libre de versos de once, siete, catorce, nueve y cinco sílabas con rima consonante. Sin embargo, a Unamuno le molesta profundamente que consideren su poesía dentro de la tendencia poética denominada modernista. Veamos lo que el poeta dice en una carta a su amigo, el vallisoletano Francisco Antón (del 9/02/1907):

"He de salir al paso a eso de que me llamen modernista. Ni por los asuntos y el fondo, ni por la forma. Esta es la que se les ha atragantado. El modernismo se propone alterar el valor de cada verso, individualmente considerado, cambiar sus acentos, etc. Yo empleo endecasílabos, eptasílabos, pentasílabos, etc., corrientes tradicionales, y todo lo que parece nuevo, sin serlo, es combinarlos libremente y sin rima. El modernismo gusta de la rima y las busca ricas; yo creo que ese bárbaro artificio, nacido en la decadencia romana, es un halago meramente sensual de oídos pocos finos y ataraza el pensamiento. Casi las mismas cosas que se me están diciendo se las dijeron a Carducci cuando empezaba y él continuó sin hacer caso, como continuaré yo. Soy vizcaíno, es decir, terco y el tiempo y yo contra todos"38

Según se deduce de las palabras de Unamuno, frente a los modernistas, que alteran el valor de cada verso -dándole a cada uno un tratamiento individualizado y cambiando los acentos-, él aboga por la combinación de versos tradicionales. Su "novedad" reside en la combinación libre y sin rima. Nuestro poeta renuncia con rotundidad al empleo de ésta ya que, según su concepto de poesía, los modernistas abusan de ella para buscar sorioridad en el verso y poder enlazar, de este modo, sus composiciones "faltas de lazo interior":

"No menos claro -argumenta en la citada carta a Vaz de Ferreira- es que el ritmo ha de responder al pensamiento poético, y cuando éste es, como creo lo es en mí, austero y hasta adusto, la forma debe serlo también. Por eso me repugna la rima, que me parece demasiado sensual. Además, la rima establece un elemento de asociación externa de ideas -rima generatrice- buena para quien hace poesía de fuera a dentro. Rubén Darío, verbigracia, necesita de la rima para enlazar y dar coherencia a sus concepciones poéticas, que suelen ser caleidoscópicas y faltas de lazo interior. Perdido ese hilo caería en impresiones desligadas, en verdadera sarta sin cuerda. Pero a mí la rima me estorba." 39

Por tanto, la diferencia esencial que percibe Unamuno entre la silva modernista y la suya propia reside en el hecho de que la primera es una poesía exterior, sonora, con artificio y que necesita la rima para crear ligazón entre los versos, mientras que la de Unamuno, que nace del dolor y la pasión, no es artificiosa, ni gusta de la sonoridad -aunque sí del ritmo- y,

presenta una terminación aguda. Este tipo de alejandrino será utilizado, posteriormente, por el propio Unamuno en los sonetos Sueño final, La encina y el sauce, Siémbrate y Noches de insomnio, de su libro Rosario de sonetos líricos (1911).

${ }^{38}$ Apud., M. García Blanco, op. cit., p. 119.

${ }^{39}$ Apud., M. García Blanco, op. cit., p. 119. 
por ello, carece de rima. Por tanto, los Salmos surgen de ese desgarro del alma y requieren un cauce métrico que permita al poeta sentir libremente el curso de sus versos:

"Esos salmos de mis Poesías, con otras varias composiciones que allí hay, son mi religión, y mi religión cantada y no expuesta lógica y razonadamente. Y la canto mejor o peor, con la voz y el oído que Dios me ha dado, porque no la puedo razonar. Y el que vea raciocinio y lógica, y método y exégesis, más que vida, en esos mis versos, porque no hay en ellos faunos, dríadas, silvanos, nenúfares, "absintios" (o sea ajenjos), ojos glaucos y otras garambainas más o menos modernistas, allá se quede con lo suyo, que no voy a tocarle el corazón con arco de violín ni con martillo." 40

Con todo, aunque Unamuno no admitía que lo llamasen modernista, contemporáneos suyos, como Juan Ramón o Darío, sí que veían en él a un poeta modernista, aunque no en la línea del propio Darío (quien se manifestó sensible a la música interior que emanaba de los versos de Unamuno). De manera que Juan Ramón menciona una doble línea de influencia modernista en la poesía española: una estética, en la que Darío se muestra como un maestro en lo formal; y otra ideológica, cuyo máximo exponente es Unamuno. Asimismo, R. Cansinos Assens, a la hora de trazar el perfil literario de Unamuno, lo valora como un "hombre modernísimo, colocado más allá de las últimas columnas del instante presente" ${ }^{\natural 1}$.

\section{Estrofa sáfica.}

La estrofa sáfica, que consta de tres endecasílabos y un pentasílabo adónico, está presente en los salmos unamunianos En el desierto y en La hora de Dios. Hagamos, a continuación, un breve recorrido por la poesía de Unamuno para ver el desarrollo que tuvo esta estrofa en el poeta salmantino y entender, de esta manera, su presencia en los dos salmos mencionados ${ }^{42}$.

Frente a los escasos ejemplos de estrofa sáfica en la poesía modernista (el Himno de las cigarras de Alfonso Reyes o la oda A Espronceda, poeta civil de Marquina), Unamuno se erige como el principal exponente de esta estrofa y, en ella, inserta diversos elementos originales que distancian al poeta de las normas clásicas trazadas para este tipo de estrofa. Así, en Salamanca, poema que aparece en la sección Castilla del volumen Poesías (1907), Unamuno combina los canónicos sáficos -acentuados en primera, cuarta y octava sílaba ("Duerme el sosiego, la esperanza duerme" y "frías y oscuras, en sus duros bancos"; vv. 17 y 94)-, con los endecasílabos acentuados en segunda y sexta ("Al pie de tus sillares, Salamanca", "Pregona eternidad tu alma de piedra"; vv. 21 y 73) y, asimismo, en tercera y sexta ("En silencio fray Luis quédase solo / meditando de Job los infortunios"; vv. 41-42) (3. $^{\text {. }}$

\footnotetext{
40 "Mi religión", op. cit., p. 374.

${ }^{41}$ R. Darío, op. cit., p. 147; J. Ramón Jiménez, op. cit., p. 233; y R. Cansino Assens, Obra Crítica, I, intrd. de A. González Troyano, Sevilla, Diputación de Sevilla, 1998, p. 35.

${ }^{42}$ Seguimos, básicamente, la exposición que lleva a cabo T. Navarro Tomás, op. cit., pp. 409-410.

${ }^{43}$ PC, I, 63-67. Sobre la pieza Salamanca, Juan Ramón dice lo siguiente: "versos de once, uno de cinco, ya sin asonante. [Es] verso libre estrófico. [el poder rítmico de las lenguas griegas y latinas dan el ritmo: el verso libre
} 
Unamuno llevó a cabo diversas variaciones sobre la estrofa sáfica en distintos poemas del libro Poesías; por ejemplo: en La basílica del Señor Santiago, de Bilbao y en Las Magnolias de la Plaza Nueva (poemas de la sección Vizcaya) ${ }^{44}$, hizo los pentasílabos esdrújulos; en Castilla y en El mar de encinas (de la sección Castilla ) ${ }^{45}$, asoció bajo la misma asonancia los pentasílabos y los endecasílabos pares (ABCb); y aplicó a la estrofa sáfica rima consonante en La huella de sangre de fuego (de la sección Narrativas) ${ }^{46}$. Otras modificaciones del poeta consistieron en la sustitución del tercer endecasílabo por un heptasílabo en las estrofas en versos sueltos de El último héroe y de En la catedral vieja de Salamanca (sección Castilla $)^{47}$, y en la adición del heptasílabo sin suprimir ningún endecasílabo de la oda Para el hogar (sección Incidentes afectivos) ${ }^{48}$.

La estrofa sáfica también está presente en la labor traductora de Unamuno y, así, la pieza Miramar, traducción de un poema de Carducci que aparece en la sección Traducciones del libro Poesías, está compuesta en la misma estrofa sáfica de la oda a Salamanca y consta de veinte, con un total de ochenta versos ${ }^{49}$. Veamos ahora la utilización de este esquema métrico de aire clasicista y modernizado en dos salmos unamunianos: la Hora de Dios y En el Desierto.

La hora de Dios consta de quince estrofas del tipo sáfico de la oda a Salamanca (tres endecasílabos y un pentasílabo final, sin rima). El otro salmo (En el Desierto) también está compuesto en la misma estrofa de versos sáficos con acentuación llana, aunque, según señala M. García Blanco, algunas de sus estrofas reciben el acento inicial, que su estructura dactílica requiere, de manera forzada ${ }^{50}$. El poema presenta características peculiares respecto a la estrofa sáfica y, así, podemos comprobar cómo Unamuno enlaza las quince estrofas de las que consta el salmo mediante la rima asonante $e$ - $o$ del pentasílabo, que cierra cada una de ellas. De esta manera, el verso "recio consuelo" (v. 4) queda enlazado -mediante la asonancia- con el verso "sin compañero" (v. 8); éste, a su vez, con el verso 12 ("los dos señeros") y, así, sucesivamente, produciéndose, de esta manera, una rima en eco que parece evocar un efecto en el que las palabras del poeta se pierden -como si de un eco se tratase-, en la lejanía del desierto, sin que puedan llegar a los oídos de Dios ${ }^{51}$.

de la estrofa]" (J. R. Jiménez, op. cit., p. 117). Asimismo, un análisis de este poema ofrece M. García Blanco, op. cit., pp. 51-67.

${ }^{44} P C, \mathrm{I}, 90-94$ y $94-96$.

${ }^{45} P C, \mathrm{I}, 61$ y $62-63$.

${ }^{46} P C, \mathrm{I}, 197-199$.

${ }^{47} P C, \mathrm{I}, 70-72$ y $74-76$.

${ }^{48} P C, \mathrm{I}, 199-201$.

${ }^{49}$ PC, I, 245-247; vid. M. García Blanco, op. cit., pp. 67-69.

${ }^{50}$ M. García Blanco, op. cit., p. 89.

${ }^{51}$ Unamuno seguirá utilizando la estrofa de sáficos y adónicos en otras composiciones, que no están incluidas en el libro Poesías ni tampoco en el Rosario de sonetos líricos (1911); por ejemplo: en La voz de la campana, poema 


\title{
Tetrástico de decasílabos y hexasílabos alternos.
}

En el Salmo III, Unamuno lleva a cabo una combinación de versos decasílabos dactílicos o hímnicos -cuyos acentos rítmicos se sitúan en tercera, sexta y novena sílabas- y hexasílabos y los agrupa en tetrásticos del tipo $\mathrm{AbAb}$, con rima consonante alterna:

\author{
“Oh, Señor, tú que sufres del mundo \\ sujeto a tu obra, \\ es tu mal nuestro mal más profundo \\ y nuestra zozobra." (vv. 1-4)
}

El decasílabo hímnico, que se especializó para la poesía hímnica desde Jovellanos y alcanzó cierta importancia en la poesía modernista -como podemos comprobar en el Himno de Guerra de Rubén Darío o A la raza de G. Valencia-, tuvo una forma especial cultivada por el modernismo (pero que ya estaba presente en la lírica de los Siglos de Oro: Sor Juana Inés de la Cruz lo empleó, por primera vez, como verso autónomo), el verso dactílico esdrújulo, que se caracterizaba por comenzar con una palabra proparoxítona y por poseer sus acentos en la primera, sexta y novena sílabas. Este tipo concreto de decasílabo dactílico lo encontramos en el verso 57 del Salmo III de Unamuno: "Méteme, Padre eterno, en tu pecho" ${ }^{\text {53 }}$. Por otra parte, la conjugación de decasílabos dactílicos y hexasílabos está presente, por ejemplo, en las Rimas VII y VIII de Bécquer y continúa en el modernismo en poemas como el Salmo III de Rubén Darío, el Idilio de Díaz Mirón o El Coco caballero del propio Unamuno -de la sección Cosas de niños de Poesías $^{54}$.

que consta de seis estrofas sáficas con rima asonante, que va hilvanando los versos pares, a saber, el segundo endecasílabo de cada estrofa, y el pentasílabo; o, en el titulado De regreso, compuesto en doce estrofas sáficas con un total de cuarenta y ocho versos, enlazados por rima asonante en - $a$ - $a$ todos los pares y también todos los versos cortos (cf. M. García Blanco, op. cit., pp. 127 y 129, respectivamente).

${ }^{52}$ Una forma métrica similar emplea Fray Luis de León en sus salmos 44b, 102b, 103, 11 y 109 y en su traducción del epodo II horaciano Beatus ille (dísticos de trímetro y dímetro yámbico): la estrofa tetrástica de endecasílabos y heptasílabos alternos, con rima consonante y esquema métrico AbAb. Esta estrofa ya se encontraba en la traslación realizada por el humanista sevillano Juan de Mal Lara del salmo 128 de Flaminio -aunque no presentaba la rima consonante alterna- y había sido destacada por el Brocense en sus Anotaciones a Garcilaso de la Vega de 1574 (cf. A. Blecua, "El entorno poético de fray Luis" en Academia Literaria Renacentista. I: Fray Luis de León, ed. de V. García de la Concha, Salamanca, Universidad, 1981, pp. 77-99, pp. 90-92; y V. Núñez, "La versión poética de los Salmos en el Siglo de Oro: vinculaciones con la oda", La oda, ed. de B. López Bueno, Universidad de Sevilla, 1993, pp. 335-382; p. 353). La estrofa mencionada fue adoptada por D. Girón en la traducción fragmentaria que lleva a cabo del Beatus ille horaciano ("Dichoso el que alejado de negocios.") y que aparece en las Anotaciones herrerianas -con la peculiaridad de que los versos heptasílabos son esdrújulos- y también por el propio Herrera en su traducción de la oda I, 8 de Horacio; cf. A. Gallego Morell, Garcilaso de la Vega y sus comentaristas, Madrid, Gredos, 1972, pp. 502-503 (Beatus ille) y pp. 415-416 (oda I, 8). Sobre esta cuestión, vid. B. López Bueno, "Implicación género-estrofa en el sistema poético del siglo XVI", Edad de Oro, XI (1992), pp. 99-111, pp. 107-109; e I. Osuna, "Tendencias métricas en las traducciones de odas clásicas en el Siglo de Oro", La Oda, pp. 383-397, p. 388 .

${ }^{53} P C, 1,115$.

${ }^{54}$ Sobre este tipo de decasílabo dactílico, véase: T. Navarro Tomás, op. cit., pp. 444-445 y R. Baehr, Manual de versificación española, trad. y adapt. de K. Wagner y F. López Estrada, Madrid, Gredos, 1989, pp. 128-135. 


\section{PROYECCIÓN DE LOS SALMOS.}

La proyección de estas composiciones poéticas de Unamuno se observa, principalmente, en dos vías diferenciadas: a) en la poesía religiosa posterior del propio Unamuno; b) en otros poetas como Jorge Guillén o Blas de Otero.

En primer lugar, cabe destacar cómo los temas esenciales que hemos visto en los Salmos de Unamuno (la falta de comunicación con Dios, la lucha entre el sentimiento y la razón, la muerte como reveladora del misterio divino, la búsqueda de Dios, etc.) perviven en determinados poemas del Rosario de sonetos líricos (1911); por ejemplo, el motivo poético de la incomunicación con Dios lo encontramos en el soneto Coloquio místico:

"Hablar con Dios meterse es hasta el fondo

del abismo; por mucho que se ahonde

no se le toca; cuanto puedo sondo

y respondo de mí, mas Dios se esconde

y es de Él, de Dios, de quien yo no respondo." (vv. 10-14)

El conflicto interior entre el sentimiento y la razón está presente en este otro poema:

"Levanta de la fe el blanco estandarte

sobre el polvo que cubre la batalla

mientras la ciencia parlotea, y calla

y oye sabiduría y obra el arte." (vv. 1-4)

Por otra parte, podemos encontrar el motivo poético de la muerte como antesala del conocimiento de Dios y de la inmortalidad en el poema Tragi-comedia:

"Y en este ministerio

cobra de la tal vida triste acedia

y la muerte es escena de comedia

aunque prólogo sea del misterio." (vv. 5-8 $)^{57}$

En estos sonetos, Unamuno no sólo recrea los temas fundamentales de los Salmos, sino que para su tratamiento conceptual se vale de los mismos símbolos, creando, por tanto, su propio universo poético y particular visión de la relación existente entre el hombre y Dios. En este sentido, imágenes poéticas con una gran riqueza simbólica como el "desierto", el "ángel", la "palabra", el "nombre", la "nube" o el "agua" se diseminan a lo largo de estos poemas; tal es el caso del símbolo de la "nube", que expresa la barrera existente entre Dios y el hombre y que hallamos en el soneto Muralla de nubes:

“(...) tu vuelo, mi alma, esa encrespada sierra

de nubes nunca franquearás, muralla

serás de tus anhelos: de la tierra

\footnotetext{
${ }^{55} P C, \mathrm{I}, 301$.

${ }^{56} P C, \mathrm{I}, 291$.

${ }^{57} \mathrm{PC}, \mathrm{I}, 306$.
} 
no la tierra, las nubes de que se halla

ceñida hacen la cerca que te encierran

en el estrecho campo de batalla." (vv. 9-14)

Otro símbolo fundamental -también de origen bíblico- es el del "desierto", como manifestación de la soledad del hombre que camina por senderos desconocidos en búsqueda de Dios:
“¡Pobre alma triste que caminas sola
perdida del desierto en las arenas,
llevando a cuestas solitarias penas
oscuras, que no brillan con la aureola" (Soledad, vv. 1-4) $)^{59}$

La rebeldía del poeta que apreciábamos, sobre todo, en el Salmo I, aflora de nuevo en la Oración final de El Cristo de Velázquez (1920):

"Tú que callas, joh Cristo!, para oírnos,

oye de nuestros pechos los sollozos" (vv. 1-2)

Los Salmos de Unamuno han alcanzado eco en la obra de otros poetas, como, por ejemplo, J. Guillén61; así, los versos Sumersión en la fuente de la vida, / Recio consuelo!, que encabezan el poema Mundo en claro de Cántico de 1945 y que, en la nueva redacción de 1950 , fueron trasladados por el poeta al final del libro para que tuviesen mayor relevancia, proceden del salmo unamuniano En el desierto ${ }^{62}$.

En relación con J. Guillén, cabe destacar también que el Salmo de la Mañana pudo dejar su huella en otros poemas de Cántico, especialmente, en el titulado Más allá, en lo que respecta a la temática, el contenido ontológico y la simbología. De hecho, podemos aducir algunos paralelismos entre estas dos composiciones mencionadas; por ejemplo: si el poema de Guillén pone de manifiesto cómo la "mañana" colma al poeta de plenitud vital -signum de la perfección del mundo-, Unamuno, por su parte, considera este momento del día como una señal de Dios, que hace revivir al hombre en un estado de gozo inefable. Del mismo modo, la simbología que predomina en ambos poemas gira en torno a la "luz", que ilumina la vida del ser humano.

Por otra parte, debemos destacar la presencia de los Salmos unamunianos en la poesía de Blas de Otero. Así, la misma actitud que adopta Unamuno en sus Salmos será retomada por Otero para manifestar la lucha de amor y rechazo entre Dios y el poeta en sus dos obras

\footnotetext{
${ }^{58} \mathrm{PC}, \mathrm{I}, 316$.

${ }^{59} \mathrm{PC}, \mathrm{I}, 309$.

${ }^{60} P C, \mathrm{I}, 428$.

${ }^{61} \mathrm{M}$. García Blanco ofrece información sobre la comunicación que mantuvieron mediante diversas cartas Unamuno y Guillén, op. cit., pp. 336-338.

${ }^{62}$ Vid. J. Montero, "Un modo de diálogo intertextual: el epígrafe literario en Cántico, de Jorge Guillén", Epos, XIII (1997), pp. 189-208; la cuestión es tratada en p. 205.
} 
claves: Ángel fieramente humano y Redoble de conciencia. Centremos nuestra atención, por ejemplo, en los siguientes versos:

“ Poderoso silencio con quien lucho

a voz en grito: grita hasta arrancarnos

la lengua, mudo Dios al que yo escucho!" (vv. 12-14)

Es evidente en ellos la influencia de los "gritos del corazón" unamunianos, además de la presencia del "Dios del silencio", motivo éste último que se encuentra también en otros poemas de Ángel fieramente humano; por ejemplo, en el titulado Hombre:

"Luchando, cuerpo a cuerpo, con la muerte,

al borde del abismo, estoy clamando

a Dios. Y su silencio, retumbando,

ahoga mi voz en el vacío inerte." (vv. 1-4)

Y en el poema "Tú, que hieres":

"Arrebatadamente te persigo.

Arrebatadamente, desgarrando

mi soledad mortal, te voy llamando

a golpe de silencio. Ven, te digo." (vv. 1-4) ${ }^{65}$

La fórmula salmística confiteor deo -que aparece en el salmo unamuniano La hora de Dios también es utilizada por Blas de Otero con un significado similar: si bien ambos adoptan una actitud confesional, Unamuno desconoce su pecado y Blas de Otero no se arrepiente de ello. La confesión peculiar de Blas de Otero aparece en la pieza poética Juicio final:
"Yo, pecador, en fin, desesperado
de sombras y de sueños: me confieso que soy un hombre en situación de hablaros de la vida. Pequé. No me arrepiento." (vv. 5-8)

Así pues, dos poetas -Unamuno y Otero- se dan la mano en el deseo de comunicarse con Dios: el primero, concibiendo algún destello de luz en la claridad de la mañana; el segundo, desde la conciencia de que el amor a Dios sólo podrá realizarse tras la muerte.

\footnotetext{
${ }^{63}$ Blas de Otero, Poesía escogida, ed. Sabina de la Cruz y Lucía Montejo, Barcelona, Vicens-Vives, 1995, p. 24. Un estudio sobre los paralelismos existentes entre Unamuno y Otero ofrece Ignacio Elizalde: "Blas de Otero y Miguel de Unamuno", en "Al amor de Blas de Otero", ed. de José Ángel Ascunce, San Sebastián, Universidad de Deusto, 1986, pp. 303-320.

${ }^{64}$ B. de Otero, op. cit., p. 20.

${ }^{65}$ B. de Otero, op. cit., p. 25.

${ }^{66}$ B. de Otero, op. cit., p. 63.
} 